\title{
Detection and Identification of Polymorphism in Mutant Strawberry (Fragaria spp.) Plants Based on Cleaved Amplified Polymorphic Sequences Molecular Markers
}

\author{
DOI: $10.18196 /$ pt.2020.109.15-20
}

\author{
Ganies Riza Aristya ${ }^{1^{*}}$, Melin Ayundai ${ }^{2}$, Fauzana Putri ${ }^{2}$, Ani Widiastuti ${ }^{3}$, Rina Sri Kasiamdari ${ }^{4^{*}}$ \\ ${ }^{1}$ Laboratory of Genetics and Breeding, Faculty of Biology, Universitas Gadjah Mada \\ ${ }^{2}$ Faculty of Biology, Universitas Gadjah Mada, Sleman, Yogyakarta 55281, Indonesia \\ ${ }^{3}$ Department of Plant Protection, Faculty of Agriculture, Universitas Gadjah Mada, Sleman, Yogyakarta 55281, Indonesia \\ ${ }^{4}$ Laboratory of Plant Systematics, Faculty of Biology, Universitas Gadjah Mada, Sleman, Yogyakarta 55281, Indonesia \\ *Corresponding author,email: ganies_riza@ugm.ac.id/rkasiamdari@ugm.ac.id
}

\begin{abstract}
Strawberry (Fragaria spp.) has a high economic value and various benefits, but the production of strawberry plants in Indonesia is still low in terms of both quantity and quality. Strawberry plant breeding can be done in various techniques, one of which is polyploidization. Polyploidization by an induction of colchicine at various concentrations in strawberry crops cv. California and Festival resulted in superior phenotype characteristics. To prove the existence of a change in ploidy in strawberry, then research at the molecular level needs to be done. The purposes of this study were to find out changes in ploidy of strawberry plants using CAPS molecular markers and to detect the polymorphism in strawberry plants quickly. The samples used were young leaves. Main procedure was the cutting of the amplified DNA using restriction enzymes of Taql and Haelll. The results showed that CAPS molecular markers were capable of detecting polymorphism quickly and efficiently in strawberry plants. Specific bands among strawberry plants having undergone polyploidization and those not having undergone polyploidization can be seen on the differences in monomorphic or polymorphic bands between the control plants and treated plants.

Keywords: CAPS, Colchicine, Strawberries
\end{abstract}

\section{ABSTRAK}

Stroberi (Fragaria spp.) memiliki nilai ekonomi tinggi dan berbagai manfaat, namun produksi tanaman stroberi di Indonesia tergolong rendah baik secara kuantitas maupun kualitas. Pemuliaan tanaman stroberi dapat dilakukan dengan berbagai teknik, salah satunya adalah poliploidisasi. Poliploidisasi dengan induksi kolkisin dalam berbagai konsentrasi tanaman stroberi kultivar Californica dan Festival menunjukkan tanaman stroberi dengan karakteristik fenotip yang unggul. Perubahan ploidi pada tanaman stroberi perlu dibuktikan dengan melakukan penelitian di tingkat molekuler. Tujuan penelitian ini adalah untuk mengetahui perubahan ploidi tanaman stroberi menggunakan marka molekuler CAPS dan mendeteksi polimorfisme secara cepat pada tanaman stroberi. Sampel yang digunakan berupa daun muda stroberi kultivar Californica and Festival. Prosedur utama yang dilakukan pemotongan hasil DNA amplifikasi dengan enzim restriksi Taql dan Haell. Hasil penelitian menunjukkan bahwa penanda molekuler CAPS mampu mendeteksi ploidi dengan cepat dan efisien polimorfisme pada tanaman stroberi. Pita spesifik antara tanaman stroberi yang telah mengalami poliploidisasi dan yang tidak poliploidisasi dapat dilihat pada perbedaan pita monomorfik atau polimorfik antara tanaman kontrol dan tanaman perlakuan.

Kata Kunci: CAPS, Kolkisin, Stroberi

\section{INTRODUCTION}

Strawberry plants are widely grown in highland areas in Indonesia. Strawberry plants are grown in some Indonesian areas such as in Lembang and Cianjur areas, West Java province. In addition, strawberry plants are grown in Banyuroto Agritourism area, Banyuroto Village, Sawangan subdistrict, Magelang district, Central Java province. Strawberry plants grow well in this area due to the low temperature that is similar to their natural habitat. Strawberry plant is one of the fruit crops having high economic value and various benefits. Strawberry fruit can be used as food in fresh or processed state. Strawberry fruit also has properties that are good for health (Budiman and Saraswati, 2005).

Strawberry plant production in Indonesia is still low in terms of both quantity and quality. Plant breeding can be done in various techniques, such as hot or cold temperature shock, pressures, and induction using chemicals. One of plant breeding techniques is polyploidization through the induction of colchicine. This study begins with the optimization of the concentration and time of colchicine induction in strawberry (Fragaria spp.) plants of California and Festival cultivars. This 
field-scale application research regarding the results of the optimization of the colchicine induction in the California and Festival cultivar-strawberry plants was carried out in Banyuroto Village, Sawangan, Magelang district. The research was continued to the cytogenetic level by characterization of chromosomes of strawberry plants cv. California and Festival by Alyza (2015) and Khoiroh (2015). Characterization of phenotype and chromosome alone could not determine the overall character of the strawberry plant. Thus, it is necessary to perform research at the molecular level.

Molecular research has been widely done by using molecular markers such as AFLP, SSR, CAPS Marker, RFLP, and RAPD. The molecular marker used in this research for the detection of polymorphism of the strawberry plant was CAPS (Cleaved Amplified Polymorphic Sequences). CAPS is a PCR based molecular marker. According to Konieczny and Ausubel (1993), the CAPS marker is also called PCR-RFLP marker. CAPS uses the amplified DNA fragments, then the PCR products are cut with restriction enzyme. The advantage of this marker is the inexpensive and simple extraction method that requires a small quantity of DNA template, as well as having codominant nature and specific locus (Matsumoto and Tsumura, 2004). The purpose of this study was to detect polymorphism in the strawberry plants cv. California and Festival to determine the capability of CAPS molecular markers in detecting polymorphism in strawberry plants quickly, as well as to know the difference in the specific bands of California and Festival cultivars.

\section{MATERIALS AND METHODS}

The research was conducted from December 2014 to May 2015. Sampling of the strawberry plant leaves was done at Banyuroto Strawberry Agritourism Center, Banyuroto Village, Sawangan Subdistrict, Magelang District. The study was conducted at the Laboratory of Genetics, Faculty of Biology and Laboratory of Genetics and Plant Breeding, Faculty of Agriculture.

The sample used was the young leaves of strawberry plants cv. California and Festival. DNA was extracted using CTAB buffer, phenol: chloroform: isoamyl alcohol (PCIA) with a ratio of 25: 24: 1, 70\% ethanol, 100\% ethanol, PVP, $\beta$-mercaptoethanol, liquid nitrogen, and tissue paper. Master mix, aquabidest sterile $\left(\mathrm{ddH}_{2} \mathrm{O}\right)$, DNA isolate, and forward and reverse primer were used to amplify DNA. Regarding the research by Kunihisa et al., (2005), the specific primer was APX4 with restriction enzyme of TaqI and the primer pair was PYDB with restriction enzyme of HaelII. DNA was cut using sterile aquabidest $\left(\mathrm{ddH}_{2} \mathrm{O}\right)$, DNA amplification, enzyme buffer, and a restriction enzyme. DNA electrophoresis was performed using loading dye, parafilm, agarose gel, TBE buffer and EtBr dye.

The equipment used were microtube with a size of $1.5 \mathrm{ml}$ and $1 \mathrm{ml}$, vortex, centrifuge, freezer, water bath, analytical balance, pipette tips and micropipette in various sizes, as well as mortar and pestle that had been sterilized. Amplification and incubation of DNA cut was performed with restriction enzyme using thermocycler. Qualitative analysis was done using electroporator, while quantitative analysis was carried outusing a spectrophotometer.

\section{DNA Extraction}

Samples were the young leaves of Festival and California cultivars. Each sample used was 0.3 gram that was replicated three times. DNA was extracted from the leaves of strawberries that were already prepared. DNA was isolated using CTAB buffer. The samples $(0.3 \mathrm{~g})$ were added with PVP $(0.02 \mathrm{~g})$ that were ground finely with liquid nitrogen. Samples were put into microtube of $1.5 \mathrm{~mL}$ plus $700 \mathrm{~mL}$ CTAB buffer that had been incubated 
at a temperature of $65^{\circ} \mathrm{C}$ for $5 \mathrm{~min}$. Next, the samples already supplemented with CTAB buffer were incubated in a water bath at a temperature of $65^{\circ} \mathrm{C}$ for $10 \mathrm{~min}$ and then incubated at $-20^{\circ} \mathrm{C}$ for $5 \mathrm{~min}$. The sample was then added with $500 \mathrm{~mL}$ of phenol-chloroform-isoamyl (24:1) and inverted for $30 \mathrm{~min}$. Afterwards, it was stored at $-20^{\circ} \mathrm{C}$ for $5 \mathrm{~min}$ and centrifuged at $10,000 \mathrm{rpm}$ for $10 \mathrm{~min}$ at $4^{\circ} \mathrm{C}$. The supernatant was removed at $200 \mathrm{~mL}$ and added with isopropanol at $1 \mathrm{x}$ volume of supernatant, gently inverted and then left overnight at $4^{\circ} \mathrm{C}$. Afterwards, the sample was centrifuged at $10,000 \mathrm{rpm}$ for $10 \mathrm{~min}$ at $4^{\circ} \mathrm{C}$. Pellet was collected and washed with absolute ethanol and then centrifuged at $14,000 \mathrm{rpm}$ for $10 \mathrm{~min}$ at $4^{\circ} 0 \mathrm{C}$. The second washing was done with $70 \%$ ethanol and centrifugation at $14,000 \mathrm{rpm}$ for $10 \mathrm{~min}$ at $4^{\circ} \mathrm{C}$. Pellet was air-dried until the residual ethanol disappeared, then added with 1 X TE buffer plus $50 \mathrm{~mL}$ and stored at $-20^{\circ} \mathrm{C}$.

\section{Qualitative and Quantitative DNA Test}

Qualitative test of genomic DNA was done using electrophoresis with an agarose gel concentration of $0.8 \%$. Gel was stained with ethidium bromide $(\mathrm{EtBr})$ for $30 \mathrm{~min}$. Results were observed under UV Transilluminator. The concentration and purity level of the isolated DNA can be identified by DNA quantitative test using a spectrophotometer. The purity of DNA solution can be calculated by comparison of wavelengths of $260 \mathrm{~nm}$ to $280 \mathrm{~nm}$. Purity limit commonly used in molecular analysis on the ratio $\mathrm{A} 260 / \mathrm{A} 280$ is 1.8 to 2.0. If the value of the ratio is less than 1.8 then there is still protein or phenol contamination in the solution (Sambrook and Russell, 2001).

\section{DNA Amplification}

The isolated DNA was amplified using a thermocycler. Specific primers used in this study were the APX-4 and PYDB (Table 1).
Tabel 1. CAPS marker primers used in the study (Kunihisa et al., 2005)

\begin{tabular}{|c|c|c|c|c|}
\hline No. & $\begin{array}{l}\text { Name of } \\
\text { CAPS-RE }\end{array}$ & $\begin{array}{l}\text { Name of } \\
\text { Specific } \\
\text { Primers }\end{array}$ & Sequence & Endonuclease \\
\hline \multirow[t]{2}{*}{1.} & $\begin{array}{l}\text { APX4- } \\
\text { Taql }\end{array}$ & APX2-Fw & $\begin{array}{l}\text { 5'- } \\
\text { GTCTCCGATCCCTAT } \\
\text { CTTTTCTTT- } 3^{\prime}\end{array}$ & Taql \\
\hline & & APX2-Rv & $\begin{array}{l}5^{\prime} \text { - } \\
\text { TCAGGTCCACCGGTG } \\
\text { ACC- } 3^{\prime}\end{array}$ & \\
\hline \multirow[t]{2}{*}{2.} & $\begin{array}{l}\text { PYDB- } \\
\text { Haelll }\end{array}$ & PYDB Fw & $\begin{array}{l}5^{\prime}- \\
\text { AGGTAAGGAACATG } \\
\text { ATCAACTTTGAG- } 3^{\prime}\end{array}$ & Haell \\
\hline & & PYDB-Rv & $\begin{array}{l}5^{\prime}- \\
\text { ATCTGAAAAACCAA } \\
\text { GTAGAAACTTACG- } 3^{\prime}\end{array}$ & \\
\hline
\end{tabular}

The amplified DNA was tested qualitatively using electrophoresis with $2 \%$ agarose gel. The optimized annealing temperature was $55.1^{\circ} \mathrm{C}$.

\section{CAPS-RE Procedures}

The amplified DNA was treated with $4 \mathrm{U}$ of endonuclease in a $0.01 \mathrm{~mL}$ volume. The products of the PCR were cut with restriction enzymes. Restriction enzymes used were TaqI for APX-4 primer and HaeIII for PYDB primer (Kunihisa et al., 2005). First, $3.5 \mathrm{~mL}$ sterile aquabidest $\left(\mathrm{ddH}_{2} \mathrm{O}\right)$ was put into microtube added with $1 \mathrm{~mL}$ reaction buffer, $5 \mathrm{~mL}$ amplified DNA and $0.5 \mathrm{~mL}$ restriction enzyme in each $10 \mathrm{~mL}$ reaction. Before the restriction enzyme was put into microtube, the reagent mixture was vortexed for about 5 seconds. Total reaction was $10 \mathrm{~mL}$ in $1 \mathrm{~mL}$ microtube.

Samples were incubated in a thermocycler (PCR) at a temperature of $65^{\circ} \mathrm{C}$ for APX4-TaqI and at $37^{\circ} \mathrm{C}$ for PYDB-HaeIII for 1 hour. After incubation, the samples were subjected to heat inactivation at a temperature of $80^{\circ} \mathrm{C}$ for $20 \mathrm{~min}$ to stop the restriction enzyme action. The results were separated by electrophoresis using an agarose gel $2 \%$ in $50 \mathrm{~V}$ for $50 \mathrm{~min}$.

\section{RESULTS AND DISCUSSION}

The results of DNA amplification using the PYDB primers and cutting of amplified DNA with 


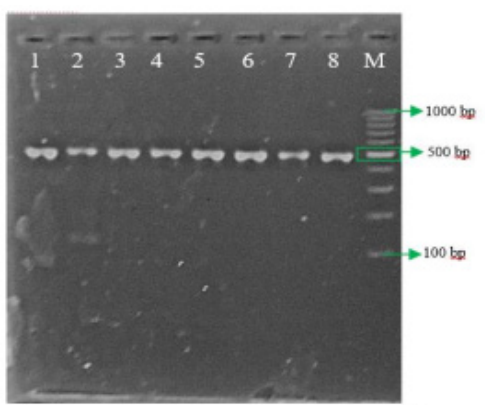
Note:
1 = California Sample 1
2 = California Sample 2
3 = California Sample 3
4 = California Sample 4
$5=$ Festival Sample 1
$6=$ Festival Sample 2
$7=$ Festival Sample 3
$8=$ Festival Sample 4
$9=$ Marker $100 \mathrm{bp}$

Figure 1. Electrophoresis of PCR products with PYDB primers using $2 \%$ agarose gel

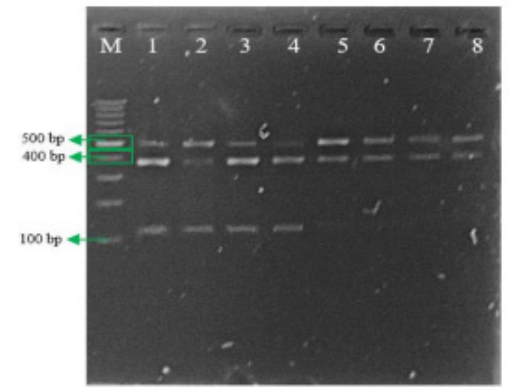

Note:

$1=$ California Sample 1

2 = California Sample 2

3 = California Sample 3

4 = California Sample 4

$5=$ Festival Sample 1

$6=$ Festival Sample 2

$7=$ Festival Sample 3

$8=$ Festival Sample 4

$9=$ Marker $100 \mathrm{bp}$

Figure 2. Cutting patterns with Haelll restriction enzyme

restriction enzyme HaelII are shown in Figure 1 and

2. The results of the electrophoresis showed the DNA amplification using PYDB primers with the size of the DNA fragment of $500 \mathrm{bp}$ in all samples of Festival and California cultivars (Figure 1). Figure 2 shows the amplification of DNA that was cut with restriction enzyme of HaeIII in California sample 3 separated into three DNA fragments with sizes of $500 \mathrm{bp}, 400 \mathrm{bp}$, and $120 \mathrm{bp}$ (Figure 2. No. 1-4). In Festival cultivar, the DNA bands were separated into two fragments with sizes of $500 \mathrm{bp}$ and 400 bp (Figure 2. No. 5-8). Figure 3 shows that all samples were amplified and existing in $400 \mathrm{bp}$ in size both in California and Festival cultivars. Figure 4 represents the electrophoresis results of amplified DNA cutting with enzyme TaqI that generates two fragments of DNA in California cultivar with sizes of $400 \mathrm{bp}$ and $300 \mathrm{bp}$. In Festival cultivars, the amplified DNA that has been restricted by enzyme does not experience separation and DNA remains in the same size with the amplification product of $40 \mathrm{bp}$.
Several steps taken in this research included DNA isolation of strawberry plants, amplification of DNA with specific primers and DNA amplification product cutting by restriction enzymes. The first step was the isolation of strawberry plant DNA using CTAB (Cetyl Trimethyl Ammonium Bromide) method following the modified protocol of Doyle and Doyle (1990). Isolation of genomic DNA of strawberry plant leaves requires optimization of the procedures and the steps of work because of the high content of secondary metabolites, polyphenols and polysaccharides. Polyphenols and polysaccharides are inhibitors in the process of DNA isolation, which can increase the viscosity of the sample, can be precipitated along with DNA that will degrade the quality of DNA, and may hamper the performance of PCR. The electrophoresis results of genomic DNA (Figure not shown) indicated that the genomic DNA bands were larger than $1 \mathrm{~kb}$, not far from well, and above DNA Ladder.

The composition of the reagents in the reaction included Nuclease Free Water (water), PCR mix, forward and reverse primer, and DNA. This total reaction was enough to do the next step, which was the cutting with a restriction enzyme. The amplified DNA was tested qualitatively by $2 \%$ agarose gel electrophoresis. Figure 1 and 3 show the amplified DNA bands with both two primers used. Target amplification size does not differ much from the reference journal, which is in range of 400-500 bp.

Primers used in the study were obtained from reference journals published by Kunihisa et al. (2005), which are specifically designed for CAPS molecular marker. Genome DNA was amplified using two specific primers of APX4 and PYDB. APX4 derived from gene APX (ascorbate peroxidase), while PYDB is single gene, representing a PYD (pyruvate decarboxylase) gene (Kunihisa et al., 2005). 


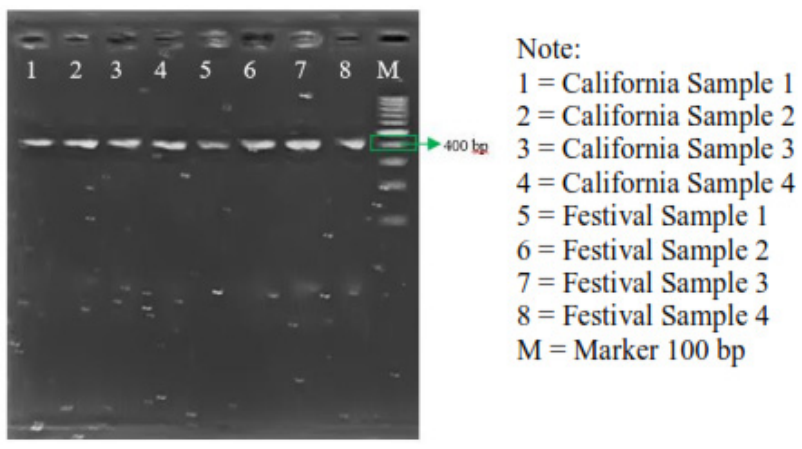

Figure 3. Electrophoresis of PCR products with APX4 primers using $2 \%$ agarose gel

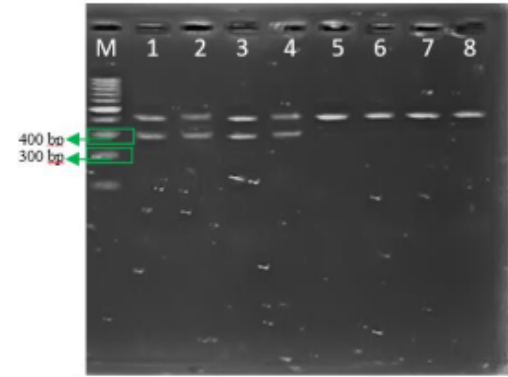
Note:
$1=$ California Sample 1 $2=$ California Sample 2
$3=$ California Sample 3
4 = California Sample 4
$5=$ Festival Sample 1
$6=$ Festival Sample 2
$7=$ Festival Sample 3
$8=$ Festival Sample 4
$\mathrm{M}=$ Marker $100 \mathrm{bp}$

Figure 4. Cutting patterns with the Taql restriction enzyme

The last step of this research was the cutting of the amplified DNA with a restriction enzyme using CAPS (Cleaved Amplified Polymorphic Sequences) method. CAPS method is a combination of RFLP and PCR methods, but the CAPS is more efficient and simpler because it does not require difficult techniques. The working principle of CAPS molecular marker is that the amplified DNA with specific primers is cut by restriction enzymes and separated by electrophoresis. The results of restriction enzyme cutting will form polymorphic and monomorphic bands, and the differences in these bands can detect genetic differences among individuals.

Restriction enzymes used were TaqI and HaeIII. Enzyme of TaqI pairs with APX4 primer, whereas HaeIII pairs with PYDB primer. Primers are designed specifically to fit the cutting point of restriction enzymes to be used. TaqI endonuclease was derived from the bacteria of Thermus aquaticus YT I , which has an identifier sequence of $\mathrm{T} \downarrow$ CGA (Sato, 1978). Meanwhile, HaeIII endonuclease discovered in 1970 was derived from species Haemophilus Aegyptus, which has the identifier sequence of GG $\downarrow$ CC (David, 1989; Fatchiyah, 2011).

When the restriction enzyme has recognized its specific sequences, the enzyme will cut phosphodiester bonds into two parts in the backbone of phosphate groups and pentose sugar of DNA double helix. In the restriction enzyme, there is a term "palindromic", which is the same recognition sequences read from the 5 'to 3' of both parts of the DNA double chains. A restriction enzyme fragment produces 3'hydroxyl $(\mathrm{OH})$ group and 5 'phosphate $\left(\mathrm{PO}_{4}^{-}\right)$group. Furthermore, the DNA becomes several fragments corresponding to the cutting area (Hartl and Jones, 1998). TaqI restriction enzyme produces fragment with asymmetric ends (sticky ends), whereas the HaeIII fragment forms blunt ends.

In Figure 2, electrophoresis with primer pairs of PYDB-HaeIII restriction enzymes showed that in all California samples, DNA bands were separated into three fragments. In the control and all Festival samples, the restriction products were separated into two DNA fragments. Polymorphism between California and Festival cultivars was clearly visible as the California and Festival cultivars showed specific and different DNA bands. Festival cultivar did not show any third DNA fragment in a size of $120 \mathrm{bp}$.

Separation by electrophoresis (Figure 4) with primer pairs of APX4-TaqI restriction enzymes in all California samples showed that they were separated into two DNA fragments. Restriction product on all Festival samples did not show separation, in which there was only one DNA band with a monomorphic band. Polymorphism between the two cultivars were obviously visible as the California cultivar showed a second DNA fragment with a size of $300 \mathrm{bp}$ that was not shared by Festival cultivar. 


\section{CONCLUSION}

The CAPS molecular markers were capable of detecting polymorphism in the strawberry plants cv. California and Festival quickly and efficiently, which showed that those cultivars had different patterns of DNA band cutting and difference in specific DNA bands. In primers of PYDB-HaeIII restriction enzymes, California cultivar showed three DNA fragments, while Festival cultivar did not have third DNA fragment that was $120 \mathrm{bp}$ in size. In primers of APX-4 TaqI restriction enzymes, California cultivar had two DNA fragments, while Festival cultivar didn't undergo segregation by restriction enzymes and didn't have a second fragment of $300 \mathrm{bp}$.

\section{REFERENCES}

Alyza, Rezika. (2015). Karakterisasi Kromosom Stroberi Festival (Fragaria x ananassa D. cv. Festival) Hasil Poliploidisasi. Naskah Skripsi. Fakultas Biologi Universitas Gadjah Mada. Yogyakarta

Budiman, S. dan D. Saraswati. (2005). Berkebun Stroberi Secara Komersial. Penebar Swadaya. Jakarta

David, R. J. (1989). Biochemistry, International Edition. ISBN 0-89278-405-9

Doyle, J. J and Doyle Doyle, J. L. (1990). Isolation of plant DNA from fresh tissue. Focus, 12: 13-15

Fatchiyah., Arumingtyas. E. L., Widyarti. S., dan Rahayu, S. (2011). Biologi Molekular Prinsip Dasar Analisis. Erlangga. Jakarta

Hartl, D. L., and E. J. Jones. (1998). Genetics: Principles and Analysis. Jones and Bartlett Publishers. Sudburry, Massachusetts

Khoiroh, R. (2015). Karakterisasi Kromosom Stroberi (Fragaria vesca L. subsp. Californica Cham. \& Schltdl. cv. Californica) Hasil Poliploidisasi. Naskah Skripsi. Fakultas Biologi Universitas Gadjah Mada. Yogyakarta

Konieczny A, Ausubel FM. (1993). A procedure for mapping Arabidopsis mutations using co-dominant ecotype-specific PCRbased markers. Plant J. Aug, 4(2):403-10

Kunihisa, M., Fukino, N., Matsumoto, S., (2005). CAPS markers improved by cluster-specific amplification for identification of octoploid strawberry (Fragariaxananassa Duch.) cultivars, and their disomic inheritance. Theor. Appl. Genet, 110: 1410-1418

Matsumoto, A. and Y. Tsumura. (2004). Evaluation of cleaved amplified polymorphic sequence markers. Theoretical and Applied Genetics, 110: 80-91

Sambrook , J., and D.W.Russel. (2001). Molecular Cloning : A Laboratory manual. $3^{\text {rd }}$ ed. Cold Spring Harbor : Cold Spring Harbor Laboratory Press. ISBN 0-87969-309-6

Sato, S. (1978). A single cleavage of Simian virus 40 (SV40) DNA by a site specific endonuclease from Thermus aquaticus, Taq I. J. Biochem. Tokyo, 83 (2): 633-5 